\title{
PENGARUH ALLOCENTRIS DAN ANIMOSITY TERHADAP NIAT BELI KONSUMEN PADA PRODUK MAKANAN LOKAL DENGAN ETHNOCENTRISM SEBAGAI INTERVENING VARIABEL
}

\author{
THE EFFECT OF ALLOCENTRISM AND ANIMOSITY ON CONSUMER PURCHASE INTENTION TOWARDS \\ LOCAL FOODS PRODUCTS WITH ETHNOCENTRISM AS INTERVENING VARIABLE
}

\author{
Sulis Riptiono*)1 \\ *) Sekolah Tinggi Ilmu Ekonomi Putra Bangsa \\ Jl. Ronggowarsito No. 18, Kebumen 54361, Indonesia
}

\begin{abstract}
The purpose of this study was to investigate the effects of consumer allocentrism towards family, allocentrism towards friends and consumer animosity toward consumer intention to purchase halal products with consumer ethnocentrism as intervening variable. Primary data were collected from 100 students in Kebumen using closed questions with questionnaires. Data were analyzed with spss for windows version 24.0. Path-analyzes was used to test relationship between variables. Based on the results, the study showed that from seven hypothesis proposed, six hypothesis are accepted and only one hypothesis is rejected. The results showed that consumer purchase intentions on local food products are influenced by variable allocentrism to family, allocentrism toward friends, and customer ethnocentrism, while animosity does not have a significant influence toward consumers purchase intention on local food products.
\end{abstract}

Keywords: allocentrism, animosity, ethnocentrism, purchase intention, local product food

\begin{abstract}
Abstrak: Tujuan dari penelitian ini adalah untuk mengetahui pengaruh allocentrism towards family, allocentrism towards friends dan consumer animosity terhadap niat konsumen untuk membeli produk halal dengan etnosentris konsumen sebagai variabel intervening. Data primer dikumpulkan dari 100 siswa perguruan tinggi di Kebumen dengan menggunakan kuesioner yang menggunakan pertanyaan tertutup. Data dianalisis dengan bantuan SPSS for windows versi 24.0. Analisis jalur digunakan untuk menguji hubungan antar variabel. Berdasarkan hasil analisis menunjukkan bahwa dari tujuh hipotesis yang diajukan, terdapat enam hipotesis yang diterima dan hanya satu hipotesis yang dinyatakan ditolak. Hasil penelitian menunjukkan bahwa niat beli konsumen pada produk makanan lokal dipengaruhi oleh variabel allocentrism towards family, allocentrism towards friends, dan etnosentrisme pelanggan, sedangkan animosity tidak berpengaruh signifikan terhadap niat beli konsumen pada produk makanan lokal.
\end{abstract}

Kata kunci: allocentrism, animosity, ethnocentrism, niat beli, produk makanan lokal

\footnotetext{
${ }^{1}$ Alamat Korespondensi:

Email: sulis.riptiono@gmail.com
} 


\section{PENDAHULUAN}

Globalisasi pasar dunia telah mempercepat persaingan antara produk lokal dan produk asing. Produsen lokal di negara berkembang seperti Indonesia harus mampu bersaing secara efektif dengan produk impor (asing). Tentunya hal ini membuat konsumen memiliki beberapa alternatif produk dari dalam dan luar negeri. Semakin banyak pilihan produk mengakibatkan konsumen sering bias dalam preferensi mereka terhadap penilaian produk dari negara mereka sendiri dibandingkan dengan orang-orang dari negara lain (Verlegh, 2007). Konsep yang digunakan untuk membenarkan bias konsumen terhadap produk yang diproduksi di dalam negeri atau produk lokal dapat dijelaskan dengan menggunakan konsep ethnocentrism konsumen (Hsu dan Nien, 2008).

Klein et al.. (1998) menyatakan bahwa konsumen etnosentris memiliki kecenderungan untuk membeli produk lokal karena mereka berkeyakinan bahwa produk yang dibuat di negara mereka sendiri dianggap lebih unggul daripada produk asing. Sementara pada negara berkembang, pengaruh ethnocentrism konsumen pada niat untuk membeli produk dalam negeri lemah yang dikarenakan oleh penilaian kualitas produk yang lebih rendah (Wang dan Chen, 2004). Studi sebelumnya menunjukkan bahwa pada suatu negara yang memiliki kecenderungan ethnocentrism yang tinggi berdampak pada pandangan konsumen pada produk asing bersifat negatif (Saffu et al.. 2010; Souiden et al.. 2018). Konsumen etnosentris mempunyai preferensi yang tinggi terhadap produk dalam negeri untuk melebihlebihkan atribut mereka serta menunjukkan preferensi yang kuat untuk membeli barang-barang negara asal (Wang dan Chen, 2004).

Konsumen etnosentris memberikan penilaian yang tidak menguntungkan terhadap produk asing dan menunjukkan keengganan untuk membeli produk ini dan mereka juga menunjukkan prasangka dan permusuhan (animosity) terhadap negara asing dan meremehkan atribut produk asing (Souiden et al.. 2018). Animosity mengacu pada ketidaksukaan yang kuat terhadap suatu negara atau kelompok etnis tertentu dan cenderung memengaruhi penilaian kognitif dan evaluasi afektif produk-produk dari negara tersebut secara negatif (Souiden et al.. 2018).
Studi sebelumnya tentang animosity konsumen telah menunjukkan melalui pemodelan persamaan struktural bahwa ethnocentrism dan animosity konsumen adalah konsep yang berbeda yang memiliki anteseden yang berbeda pula (Leong et al.. 2008; Fernández-ferrín et al.. 2015). Ethnocentrism konsumen menangkap kepercayaan tentang kesesuaian moral membeli produk asing secara umum. Sebaliknya, konstruk animosity konsumen menangkap kemarahan terhadap suatu negara tertentu dan memprediksi kemauan untuk membeli produk dari negara tertentu (Klein et al. 1998). Beberapa konsumen mungkin menolak untuk membeli produk dari negara tertentu tetapi bersedia untuk membeli produk yang diimpor dari negara lain (Klein et al.. 1998). Meskipun ethnocentrism dan animosity memiliki anteseden yang berbeda-beda tetapi beberapa studi menunjukkan konsekuen terhadap niat beli produk lokal (Bada dan Onuoha, 2018; Souiden et al.. 2018; Quang et al.. 2017; Fakharmanesh dan Miyandehi, 2013; Nguyen et al.. 2008).

Verlegh (2007) mengemukakan bahwa hubungan antara ethnocentrism dan identifikasi nasional adalah positif. Namun, dalam kondisi dan situasi tertentu peran identitas sosial dan motivasi ethnocentrism mempunyai hubungan yang berlawanan arah (Huang et al.. 2008). Studi-studi sebelumnya tentang CET, khususnya identitas dalam kelompok, meninggalkan celah dalam pemahaman kita tentang hubungan antara allocentrism dan ethnocentrism (Huang et al.. 2008). Dalam kasus tertentu dimana konsumen berada dalam beberapa kelompok yang diidentifikasi (misalnya, keluarga dan teman) umumnya dianggap lebih penting daripada kelompok nasional (Huang et al.. 2008). Sebagai contoh, allocentrism mungkin memainkan peran penting dalam situasi di mana beberapa kelompok yang teridentifikasi (misalnya, Keluarga dan teman) lebih suka produk lokal daripada produk asing (Shankarmahesh, 2006).

Tinjauan literatur yang relevan telah mengungkapkan bahwa penelitian terdahulu yang dilakukan oleh Huang et al. (2010) telah gagal untuk memberikan bukti empiris untuk hubungan antara allocentrism dan ethnocentrism, sedangkan Selli dan Kurniawan (2014) menyatakan bahwa allocentrism mampu memberikan pengaruh yang positif terhadap consumer ethnocentrism. Oleh karena itu, penting dilakukan riset lebih lanjut untuk menguji efek dari allocentrism pada ethnocentrism lebih lanjut dan dampaknya terhadap niat beli untuk dapat memahami mengapa konsumen tertentu memilih produk dalam negeri sementara yang lain lebih suka 
produk asing. Beberapa produk asing yang diimpor ke Indonesia misalnya makanan, kain, kerajinan, dan lainnya merupakan produk yang memiliki nilai budaya tersendiri. Makanan merupakan kebutuhan primer manusia yang harus dipenuhi, kebutuhan makanan dapat dipenuhi dengan produk makanan yang tersedia dalam berbagai tipe, bentuk dan beragam jenisnya (Rahmawati dan Muflikhati, 2016). Pemasaran makanan lokal telah menjadi tren yang populer di seluruh industri makanan dan industri ritel makanan selama dekade terakhir, peningkatan permintaan konsumen untuk makanan lokal juga mencerminkan tren konsumen yang lebih besar yang mendukung produk makanan lokal (Remar et al. 2016).

Tujuan utama dari penelitian ini adalah untuk mengembangkan model multidisiplin dari pemasaran, psikologi dan sosiologi untuk memperkaya pemahaman kita tentang perilaku konsumen yang berkaitan dengan efek animosity dan allocentrism terhadap ethnocentrism konsumen dan niat beli konsumen pada produk makanan lokal. Kontribusi penelitian ini menawarkan bukti empiris pada sejauh mana variabel sosio-psikologis yang terkait dengan produk lokal (animosity, allocentrism, dan ethnocentrism) dapat memberikan pengaruh pada niat beli makanan lokal.

\section{METODE PENELITIAN}

Penetitian yang digunakan dalam studi ini merupakan jenis penelitian kuantitatifkausal dengan metode survey. Metode ini melibatkan 100 mahasiswa yang masih tinggal bersama orang tua sebagai responden untuk mengetahui niat beli konsumen pada produk makanan lokal (misal: Nasi Penggel, Sate Ambal, Lanting, Jipang Kacang, Kethek, Sale Pisang) di Kebumen. Sampel ditentukan dengan metode non-probability sampling dengan menggunakan tehnik purposive sampling, dimana responden memiliki kriteria yaitu mengetahui dan memahami produk makanan lokal dan makanan asing, serta memahami tentang nilai-nilai budaya lokal khusunya produk lokal Kebumen.

Penelitian ini menggunakan 3 jenis variabel, yaitu variabel independent (allocentrism dan animosity), variabel intervening (consumer ethnocentrism) dan variabel dependent (niat beli konsumen). Allocentrism dalam penelitian ini dibedakan menjadi dua variabel yaitu allocentrism toward family dan allocentrism toward friends dan diukur dengan menggunakan masing-masing dua item pertanyaan yang diadopsi dari Huang et al. (2008). Pernyataan dalam kuesioner yang digunakan untuk mengukur variabel allocentrism toward family seperti: "Sebagai seorang anak harus mendengarkan saran dari orang tua" dan "Sudah sewajarnya bagi seorang anak untuk melanjutkan bisnis ayahnya." Allocentrism toward friend, seperti: "menyukai untuk tinggal dengan teman baik" dan "mempunyai kesepakatan untuk berbelanja di suatu tempat yang sama."Variabel animosity diukur dengan menggunakan tiga item pertanyaan yang dikembangkan oleh Souiden et al. (2018), seperti: "Saya tidak menyukai produk makanan asing", "Saya merasa marah terhadap produk makanan asing" dan "Keberadaan produk makanan asing membuat kerugian produk makanan lokal"

Consumer ethnocentrism diukur dengan menggunakan enam item pertanyaan yang diadopsi dari Klein et al. (1998), Quang et al. (2017) dan Khan et al. (2019). Item kuesionernya adalah sebagai berikut: (a) Produk Indonesia adalah produk yang paling utama; (b) Membeli produk buatan luar negeri bukan merupakan tindakan orang Indonesia; (c) Tindakan membeli produk asing adalah tindakan tidak benar, karena menyebabkan orang Indonesia kehilangan pekerjaan; (d) Membeli produk asing akan membuat kaya Negara lain; (e) Kita sebaiknya membeli dari Negara lain hanya untuk produk-produk yang tidak dapat kita peroleh dari Negara kita sendiri: (f) Konsumen Indonesia yang membeli produk-produk yang dibuat di Negara lain bertanggung jawab dalam mengakibatkan rekan/ kerabat sesama orang Indonesia tidak bekerja.

Sedangkan untuk variabel niat beli diukur dengan menggunakan 3 item pertanyaan yang diadopsi dari Shin dan Hancer (2016), seperti: "Saya berharap membeli produk makanan lokal", "Saya ingin membeli produk makanan lokal" dan "Saya berniat untuk membeli produk makanan lokal"

Skala pengukuran yang digunakan dalam penelitian ini adalah tipe skala likert. Jawaban dari setiap instrumen menggunakan skala Likert dengan 5 skala memiliki gradasi dari sangat tidak setuju diberi skor 1 ke sangat setuju diberi skor 5. Data dikumpulkan menggunakan instrument penelitian berupa kuesioner. Setelah data terkumpul, kuesioner diuji validitas dan reliabilitasnya kemudian data yang diperoleh diolah dengan menggunakan bantuan software SPSS versi 24.0. Untuk mengetahui pengaruh masing-masing variabel yang 
diujikan digunakan analisis jalur. Kerangka pemikiran penelitian selengkapnya pada Gambar 1.

Allocentrism adalah kecenderungan untuk mendefinisikan diri sendiri dalam hubungannya dengan orang lain dan sering digunakan untuk mengukur orientasi tingkat individu yang mencerminkan nilainilai kolektivisme (Triandis, 1989). Allocentrism menggambarkan sejauh mana konsumen memiliki kecenderungan untuk terlibat dalam sebuah perilaku yang terjadi dalam kelompok dan memusatkan perhatian mereka pada kebutuhan orang lain daripada diri mereka sendiri (Bradford et al. 2019). Kelompokkelompok yang memiliki kedekatan emosional dapat memberikan tekanan sosial yang kuat (seperti keluarga, kerabat, pasangan, teman dekat) untuk meningkatkan niat seseorang dalam berperilaku (Riptiono, 2019).

Penelitian yang membahas hubungan antara allosentrism dan ethnocentrism konsumen masih relatif sedikit (Huang et al. 2010; Selli dan Kurniawan, 2014). Oleh karena itu, pertanyaan lain yang perlu dijawab adalah apakah allosentrism atau tidak terhadap produk domestik dan asing dapat dimediasi oleh kecenderungan ethnocentrism konsumen (Klein et al. 1998; Selli dan Kurniawan, 2014). Beberapa penelitian menemukan bahwa individu dengan tujuan allosentrism cenderung mengungkapkan kecenderungan ethnocentrism yang lebih intensif daripada mereka yang memiliki tujuan idiosentris (Sharma et al. 1995; Shankarmahesh, 2006). Huang et al. (2010) menunjukkan semakin tinggi tingkat alokasi seseorang terhadap teman-teman juga akan meningkatkan tingkat ethnocentrism konsumen. Selain itu, beberapa studi terdahulu berhasil mengungkapkan bahwa allocentrism juga dapat memengaruhi niat beli konsumen terhadap suatu produk (Huang et al. 2010; Selli dan Kurniawan, 2014).

Dalam bidang perilaku konsumen dan pemasaran, istilah animosity pertama kali diperkenalkan oleh (Klein et al. 1998) yang didefinisikan sebagai "sisa-sisa antipati terkait dengan peristiwa militer, politik, atau ekonomi yang sebelumnya atau sedang berlangsung yang mempengaruhi kesediaan konsumen untuk membeli produk-produk asing". Selama dekade terakhir, konsep permusuhan konsumen telah mendapat perhatian besar dalam literatur pemasaran internasional sebagai anteseden dari niat pembelian produk lokal (Fakharmanesh dan Miyandehi, 2013; Quang et al. 2017). Animosity mempunyai dampak negatif dengan niat beli dan berhubungan positif dengan ethnocentrism konsumen, klasifikasi ini digunakan secara populer dalam studi yang terkait dengan animosity dan dampaknya terhadap perilaku konsumen (Quang et al. 2017) . Konsumen dengan animosity yang tinggi terhadap produk asing akan memiliki niat yang lebih rendah untuk membeli produk asing (Fong et al. 2013) dan berpengaruh terhadap meningkatnya ethnocentrism konsumen serta berpotensi untuk menumbuhkan niat beli konsumen pada produk lokal (Souiden et al. 2018).

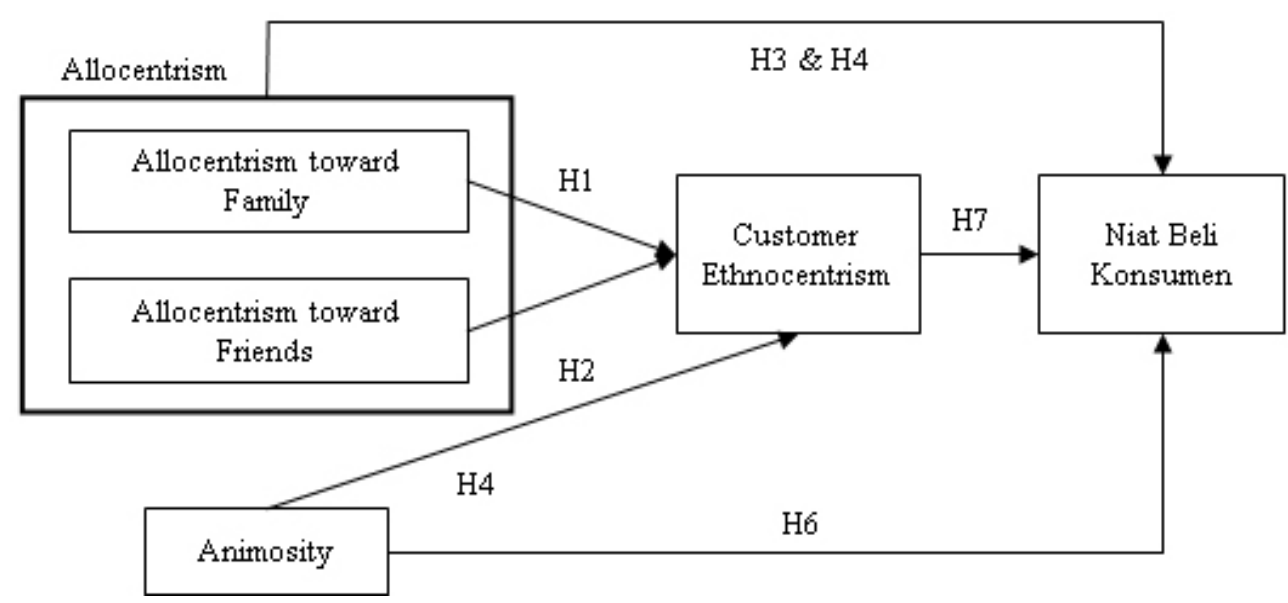

Gambar 1. Kerangka pemikiran penelitian 
Ethnocentrism konsumen menjadi kajian yang menarik untuk dilakukan penelitian dalam pemasaran (Sharma et al. 1995; Siamagka dan Balabanis, 2015; Yen, 2018). Konsumen etnosentris cenderung menilai tinggi apa yang menjadi milik kelompok mereka sendiri (seperti barang dan jasa) dan mengevaluasi apa yang bukan milik kelompok mereka, sehingga mengarah pada bias dalam evaluasi dan niat mereka untuk membeli produk buatan dalam dan luar negeri (Nguyen et al. 2008). Ethnocentrism konsumen memiliki preferensi yang lebih tinggi terhadap produk lokal atau domestik dibandingkan dengan produk asing, preferensi ini ditimbulkan karena afiliasi dan keterikatan mereka dengan bangsa mereka bahkan ketika produk identik dalam semua hal, produk lokal lebih disukai daripada produk asing (Khan et al. 2018). Hamin et al. (2014) menemukan bahwa konsumen di negara berkembang, seperti Cina, India dan Rusia, tertarik untuk membeli merek negara mereka sendiri dan bahwa konsumen ini percaya bahwa ethnocentrism mendorong konsumen untuk membeli produk dalam negeri. Oleh karena itu, kita dapat mengasumsikan bahwa hubungan antara ethnocentrism konsumen dan kemauan untuk membeli produk dalam negeri berkorelasi positif di negaranegara berkembang.

Berdasarkan kajian penelitian sebelumnya yang dilakukan oleh Huang et al. (2010), Selli dan Kurniawan (2014), Quang et al. (2017), Souiden et al. (2018), dan Kiriri, (2019) maka dapat diformulasikan hipotesis sebagai berikut:

H1 : Allocentrism toward Family berpengaruh positif terhadap customer ethnocentrism

H2 : Allocentrism toward Friends berpengaruh positif terhadap customer ethnocentrism

H3 : Animosity konsumen terhadap produk asing berpengaruh positif terhadap ethnocentrism konsumen

H4 : Allocentrism toward Family berpengaruh positif terhadap niat beli konsumen pada makanan lokal

H5 : Allocentrism toward Friends berpengaruh positif terhadap niat beli konsumen pada makanan lokal

H6 : Animosity konsumen terhadap produk asing berpengaruh positif terhadap niat beli konsumen pada produk makanan lokal

H7 : Ethnocentrism konsumen berpengaruh positif terhadap niat beli konsumen pada makanan lokal

\section{HASIL}

\section{Uji Validitas dan Reliabilitas}

Suatu kuesioner dikatakan valid apabila pernyataan yang diajukan pada kuesioner tersebut mampu mengungkap sesuatu yang akan diukur pada kuesioner tersebut. Uji reliabilitas digunakan untuk mengetahui kehandalan kuesioner peneliti yang digunakan.

Uji validitas dalam penelitian ini menggunakan Product Moment Corelation, dengan degree of freedom $(\mathrm{df})=$ $\mathrm{n}-2(\mathrm{df}=100-2=98)$ dengan taraf signifikan 5\% dan $\mathrm{r}$ tabel sebesar 0,195. Uji reliabilitas butir dilakukan dengan ketentuan jika $r$ alpha $>0,7$ maka butir atau variabel tersebut reliabel dan sebaliknya, jika $r$ alpha $<0,70$ maka butir atau variabel tersebut tidak reliabel (Ghozali, 2011). Tabel 1 menunjukkan bahwa semua parameter yang digunakan dalam model penelitian ini dinyatakan valid dan reliabel.

\section{Uji Hipotesis dan Analisis Jalur I}

Analisis jalur pada persamaan struktural I digunakan untuk menguji pengaruh langsung variabel allocentrism toward familly, allocentrism toward friends, dan animosity terhadap variabel customer ethnocentrism. Dari Tabel 2 maka dapat dibentuk persamaan regresi pada persamaan struktural I sebagai berikut:

$$
\mathrm{Y} 1=0,4367 \mathrm{X} 1+0,193 \mathrm{X} 2+0,308 \mathrm{X} 3+\mathrm{e} 1
$$

Hasil Pengujian H1: Pengaruh allocentrism toward family terhadap consumer ethnocentrism

Berdasarkan hasil pengujian diketahui bahwa nilai t hitung $(5,096)$ lebih besar dari nilai t tabel $(1,985)$, dengan nilai signifikansi kurang dari 0,05 , yaitu sebesar 0,000, maka dapat disimpulkan bahwa hasil pengujian pada hipotesis pertama dinyatakan diterima. Sedangakan besarnya pengaruh dan hubungan antara variabel ini adalah positif 0,436 . Hal ini berarti bahwa allocentrism toward friend mampu menjadi preditor bagi consumer ethnocentrism. Hasil penelitian ini sejalan dengan penelitian yang dilakukan oleh (Huang et al. 2008) 
Tabel 1. Hasil uji validitas dan reliabilitas

\begin{tabular}{|c|c|c|c|c|c|}
\hline Variabel & $\mathrm{r}$ hitung & $\mathrm{r}$ tabel & Alpha Cronbach & Nilai Kritis & Keterangan \\
\hline Allocentrism twd Familly & & & 0,703 & 0,7 & \\
\hline Pernyataan 1 & 0,830 & 0,195 & & & Valid \& Reliabel \\
\hline Pernyataan 2 & 0,828 & 0,195 & & & Valid \& Reliabel \\
\hline Allocentrism twd Friend & & & 0,737 & 0,7 & \\
\hline Pernyataan 1 & 0,886 & 0,195 & & & Valid \& Reliabel \\
\hline Pernyataan 2 & 0,888 & 0,195 & & & Valid \& Reliabel \\
\hline Animosity & & & 0,827 & 0,7 & \\
\hline Pernyataan 1 & 0,886 & 0,195 & & & Valid \& Reliabel \\
\hline Pernyataan 2 & 0,923 & 0,195 & & & Valid \& Reliabel \\
\hline Pernyataan 3 & 0,751 & 0,195 & & & Valid \& Reliabel \\
\hline Customer Ethnocentrism & & & 0,924 & 0,7 & \\
\hline Pernyataan 1 & 0,792 & 0,195 & & & Valid \& Reliabel \\
\hline Pernyataan 2 & 0,835 & 0,195 & & & Valid \& Reliabel \\
\hline Pernyataan 3 & 0,900 & 0,195 & & & Valid \& Reliabel \\
\hline Pernyataan 4 & 0,894 & 0,195 & & & Valid \& Reliabel \\
\hline Pernyataan 5 & 0,873 & 0,195 & & & Valid \& Reliabel \\
\hline Pernyataan 6 & 0,828 & 0,195 & & & Valid \& Reliabel \\
\hline Niat Beli Konsumen & & & 0,852 & 0,7 & \\
\hline Pernyataan 1 & 0,893 & 0,195 & & & Valid \& Reliabel \\
\hline Pernyataan 2 & 0,900 & 0,195 & & & Valid \& Reliabel \\
\hline Pernyataan 3 & 0,794 & 0,195 & & & Valid \& Reliabel \\
\hline
\end{tabular}

Tabel 2. Hasil Uji Regresi Persamaan Struktural I

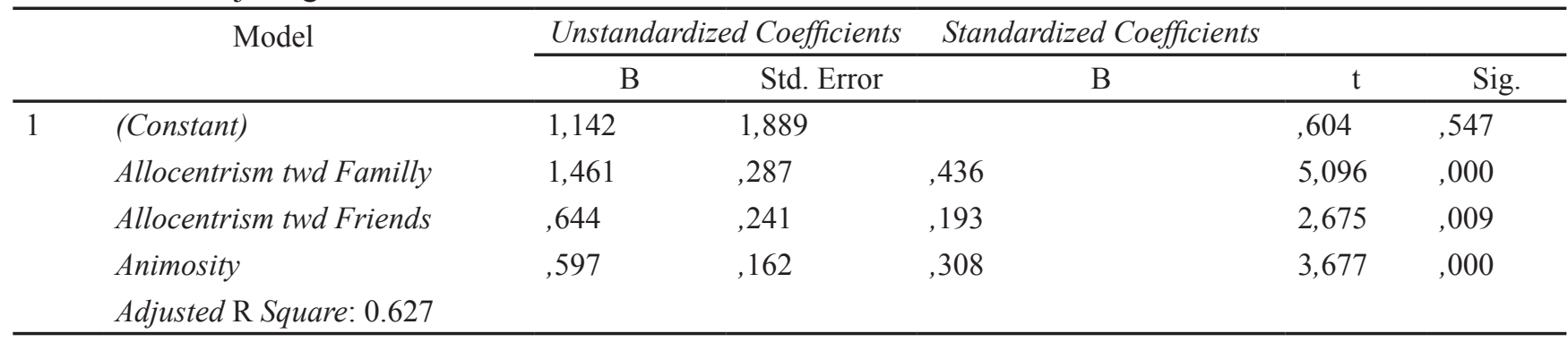

Hasil Pengujian H2: Pengaruh allocentrism toward friends terhadap customer ethnocentrism

Hasil pengujian hipotesis kedua diketahui bahwa nilai t hitung $(2,675)$ lebih besar dari nilai t tabel $(1,985)$, maka dari itu pengujian pada hipotesis kedua dinyatakan diterima. Sedangkan besarnya pengaruh dan hubungan antara variabel ini adalah positif 0,193 . Hal ini berarti bahwa penggaruh allocentrism toward friends adalah signifikan pada taraf signifikansi 0,05 . Hasil penelitian ini memiliki persamaan dengan penelitian sebelumnya yang dilakukan oleh Selli dan Kurniawan (2014).
Hasil Pengujian H3: Pengaruh animosity terhadap customer ethnocentrism

Berdasarkan hasil pengujian hipotesis ketiga diketahui bahwa nilai $\mathrm{t}$ hitung $(3,677)$ lebih besar dari nilai $\mathrm{t}$ tabel (1.985), maka dari itu pengujian pada hipotesis ketiga dinyatakan diterima. Artinya, bahwa variabel animosity mampu memberikan pengaruh terhadap variabel ethnocentrism pada taraf signifikansi 0,05 . Sedangakan besarnya pengaruh dan hubungan antara variabel ini adalah positif 0,308 . Hasil penelitian ini mempunyai kesamaan dengan penelitian terdahulu (Huang et al. 2010; Selli dan Kurniawan, 2014) yang menyatakan bahwa variabel animosity dapat berperan sebagai anteseden dari consumer ethnocentrism. 
Sementara untuk uji koefisien determinasi pada persamaan regresi struktural I dapat tentukan berdasarkan nilai adjusted $\mathrm{R}$ square sebesar 0.627 , hal ini berarti pengaruh variabel allocentrism toward family, allocentrism toward friend, dan animosity dapat memberikan pengaruh terhadap variabel customer ethnocentrism sebesar $62.7 \%$ sedangkan sisanya sebesar $37,3 \%$ dipengaruhi oleh variabel lain diluar model penelitian ini.

\section{Uji Hipotesis dan Analisis Jalur II}

Analisis jalur pada persamaan struktural II digunakan untuk menguji pengaruh langsung variabel allocentrism toward familly, allocentrism toward friends, animosity dan customer ethnocentrism terhadap variabel niat beli konsumen pada produk makanan lokal. Data diolah dengan SPSS 24.00. Berdasarkan Tabel 3 maka dapat dibentuk persamaan regresi pada persamaan struktural II sebagai berikut:

$\mathrm{Y} 2=0.291 \mathrm{X} 1+0.216 \mathrm{X} 2+0.023 \mathrm{X} 3+0.365 \mathrm{Y} 1+\mathrm{e} 1$

Hasil Pengujian H4: Pengaruh allocentrism toward family terhadap niat beli konsumen

Hasil pengujian diketahui bahwa nilai t hitung $(2,836)$ lebih besar dari nilai $\mathrm{t}$ tabel $(1,985)$, maka dari itu pengujian pada hipotesis keempat dinyatakan diterima. Sedangakan besarnya pengaruh dan hubungan antara variabel ini adalah positif 0,291. Hasil ini menunjukkan bahwa allocentrism toward family mampu memberikan pengaruh terhadap niat beli konsumen untuk membeli produk makanan lokal pada taraf signifikan 0,05. Penelitian ini memiliki persamaan dengan penelitian sebelumnya (Huang et al. 2010), yang menyatakan bahwa allocentrism toward family dapat digunakan sebagai predictor dari niat beli konsumen.

Hasil Pengujian H5: Pengaruh allocentrism toward friends terhadap niat beli konsumen

Berdasarkan hasil pengujian diketahui bahwa nilai $\mathrm{t}$ hitung $(2,712)$ lebih besar dari nilai $\mathrm{t}$ tabel $(1,985)$, maka dari itu pengujian pada hipotesis kelima dinyatakan diterima. Sedangakan besarnya pengaruh dan hubungan antara variabel ini adalah positif 0,216. Artinya, bahwa allocentrism toward friends dapat memberikan pengaruh positif terhadap niat beli konsumen untuk membeli produk makanan lokal pada taraf signifikansi 0,05 . Hasil penelitian ini sesuai dengan penelitian sebelumnya (Selli dan Kurniawan, 2014) yang mengungkapkan bahwa allocentrism toward friends sebagai anteseden yang kuat dari niat beli konsumen.

Pengujian H6: Pengaruh animosity terhadap niat beli konsumen

Hasil pengujian diketahui bahwa nilai thitung $(0,245)$ lebih kecil dari nilai $\mathrm{t}$ tabel $(1,985)$, maka dari itu pengujian pada hipotesis keenam dinyatakan ditolak. Hal ini berarti bahwa animosity konsumen tidak mampu memberikan pengaruh pada niat beli produk makanan lokal pada taraf signifikansi 0,05 . Hasil penelitian berbeda dengan penelitian terdahulu (Fernándezferrín et al. 2015; Kiriri, 2019) tetapi sejalan dengan penelitian (Ramadania et al. 2013) yang menyatakan bahwa animosity tidak mampu memberikan pengaruh terhadap niat beli konsumen.

Tabel 3. Hasil Uji Regresi Persamaan Struktural II

\begin{tabular}{llccccc}
\hline \multirow{2}{*}{ Model } & \multicolumn{2}{c}{ Unstandardized Coefficients } & Standardized Coefficients & & \\
\cline { 2 - 6 } & (Constant) & B & Std. Error & B & t & Sig. \\
\hline 1 & 1,014 & 1,043 & &, 973 &, 333 \\
Allocentrism twd Familly &, 505 &, 178 &, 291 & 2,836 &, 006 \\
Allocentrism twd Friends &, 373 &, 138 &, 216 & 2,712 &, 008 \\
Animosity &, 023 &, 095 &, 023 &, 245 &, 807 \\
Ethnocentrism &, 189 &, 056 &, 365 & 3,358 &, 001 \\
Adjusted R Square: 0.578 & & & & & \\
\hline
\end{tabular}


Pengujian H7: Pengaruh customer ethnocentrism terhadap niat beli konsumen

Hasil pengujian diketahui bahwa nilai t hitung $(3,358)$ lebih besar dari nilai t tabel $(1,985)$ maka dari itu pengujian pada hipotesis ketujuh dinyatakan diterima. Besarnya pengaruh dan hubungan antara variabel ini adalah positif 0,365 . Hal ini berarti bahwa variabel customer ethnocentrism mampu memberikan pengaruh terhadap niat beli konsumen pada taraf signifikansi 0,05 . Hasil penelitian ini sejala dengan penelitian terdahulu (Han dan Guo, 2018; Kiriri, 2019) yang membuktikan bahwa customer ethnocentrism sebagai mampu menjadi anteseden variabel niat beli konsumen.

Sedangkan pada uji koefisien determinasi pada persamaan regresi struktural II dapat tentukan berdasarkan nilai adjusted $\mathrm{R}$ square sebesar 0.578 , hal ini berarti pengaruh variabel allocentrism toward family, allocentrism toward friend, animosity dan customer ethnocentrism dapat memberikan pengaruh terhadap variabel niat beli konsumen pada makanan lokal sebesar $57,8 \%$ sedangkan sisanya sebesar 42,2 dipengaruhi oleh variabel lain diluar model.

\section{Implikasi Manajerial}

Temuan penelitian yang ini menunjukkan bahwa konsumen etnosentris mempunyai niat untuk membeli produk buatan dalam negeri yang lebih tinggi. Pemahaman tentang konsep etnosentrisme konsumen mengarah pada pemahaman yang lebih baik tentang alasan konsumen untuk membeli produk dalam negeri. Dengan demikian, memahami kecenderungan etnosentris di antara kelompok konsumen domestik dapat membantu pemasar atau perusahaan dalam merumuskan rencana pemasaran yang lebih baik. Meskipun animosity tidak terbukti berpengaruh secara langsung terhadap niat beli, tetapi animosity mampu memberikan efek terhadap meningkatnya etnosentrisme konsumen. Hal ini tentunya memberikan implikasi kepada pemasar domestik untuk lebih mengkomunikasikan kepada konsumen untuk selalu menyukai produk domestik misalnya dengan cara meningkatkan kampanye produk lokal.

Studi ini menunjukkan bahwa allocentrism berhubungan positif dengan etnosentris konsumen dan niat untuk membeli produk lokal. Allocentrism toward family dan allocentrism toward friends keduanya mampu memberikan pengaruh terhadap etnosentrisme konsumen maupun niat beli mereka terhadap produk lokal, tentunya hal ini dapat digunakan dengan baik oleh pemasar untuk menjelaskan perbedaan generasi untuk menarik konsumen. Karenanya, konsumen dapat dipengaruh teman-teman dalam kelompok dan keluarga. Dengan demikian, pemasar mungkin perlu memperkuat fokus mereka pada teman dalam kelompok dan keluarga. Maka dari itu, implikasi managerial dalam penelitian ini secara umum memberikan wawasan yang lebih mendalam tentang etnosentrisme konsumen dan animosity, dan allocentrism konsumen sehingga dapat mengarah pada strategi pemasaran yang lebih efektif.

\section{KESIMPULAN DAN SARAN}

\section{Kesimpulan}

Hasil penelitian ini mengungkapkan beberapa poin penting untuk dapat meningkatkan niat beli konsumen pada produk makanan lokal. Pertama, allocentrism toward family dan allocentrism toward friend terbukti dapat berperan sebagai anteseden dari etnhnocentrism konsumen, hal ini didukung berdasarkan hasil uji $\mathrm{H} 1, \mathrm{H} 2$, dan $\mathrm{H} 3$ yang dinyatakan diterima. Kedua, allocentrism toward family, allocentrism toward friend dan customer etnhnocentrism konsumen memliki pengaruh yang positif dan signifikan terhadap niat beli konsumen pada produk makanan lokal, tetapi variabel animosity tidak mempunyai pengaruh terhadap niat beli konsumen. Hal ini didukung dari hasil pengujian hipotesis yang menyatakan $\mathrm{H} 4, \mathrm{H} 5$, dan $\mathrm{H} 7$ diterima tetapi menolak H6. Ketiga, diantara variabel yang digunakan dalam model penelitian ini ditemukan bahwa untuk variabel allocentrism toward family mempunyai pengaruh yang paling besar terhadap variabel customer ethnocentrism sedangkan variabel yang mempunyai pengaruh terbesar terhadap niat beli konsumen adalah customer ethnocentrism.

\section{Saran}

Hasil analisis dan pembahasan yang dikemukakan bahwa allocentrism toward family merupakan variabel yang memiliki pengaruh terbesar dalam meningkatkan customer ethnocentrim, maka pemasar harus lebih fokus dalam memasarkan produknya pada target pasar yang tepat yaitu keluarga, hal ini disebabkan keluarga mampu memberikan pengaruh yang besar kepada konsumen yang masih tinggal bersama keluarga. Untuk meningkatkan niat beli konsumen pada produk 
makanan lokal khususnya di Kabupaten Kebumen, maka penting bagi pemasar untuk memperhatikan produk-produk lokal terutama yang berkaitan dengan etnosentris konsumen. Sedangkan untuk penelitian yang akan datang, berdasarkan hasil uji determinasi masih ada peluang untuk menggunakan variabel lain diluar model seperti country of origin, product image, kualitas produk dan sebagainya.

\section{DAFTAR PUSTAKA}

Bada BV, Onuoha CU. 2018. Influence of customer loyalty, consumer aanimosity and purchase intention on consumer ethnocentrism. European Scientific Journal 14(11): 125-136. https://doi. org/10.19044/esj.2018.v14n11p125.

Bradford KD et al. 2019. Harnessing internal support to enhance customer relationships: the role of networking, helping, and allocentrism. Journal of Marketing Theory and Practice 27(2): 140158. https://doi.org/10.1080/10696679.2019.15 77687.

Fakharmanesh S, Miyandehi RG. 2013. The purchase of foreign products: the role of brand image, ethnocentrism and animosity: Iran. Market Evidence 6(1): 145-160.

Fernández-ferrín P et al. 2015. Consumer ethnocentrism and consumer animosity: antecedents and consequences. International Journal of Emerging Markets 10(1): 73-88. https://doi.org/10.1108/ IJOEM-11-2011-0102.

Hamin H, Baumann C, Tung RL, Baumann C. 2014. Attenuating double jeopardy of negative country of origin effects and latecomer brand an application study of ethnocentrism. Asia Pasific Journal of Marketing and Logistics 26(1): 54-77. https://doi.org/10.1108/APJML-07-2013-0090.

Han CM, Guo C. 2018. How consumer ethnocentrism (cet), ethnocentric marketing, and consumer individualism affect ethnocentric behavior in China. Journal of Global Marketing 31(5):1-15. https://doi.org/10.1080/08911762.2018.143764 9.

Hsu JL, Nien H. 2008. Who are ethnocentric? examining consumer ethnocentrism in Chinese Societies. Journal of Consumer Behaviour 7: 436-447. https://doi.org/10.1002/cb.262.

Huang YA, Phau I, Lin C. 2010. Effects of animosity and allocentrism on consumer ethnocentrism: social identity on consumer willingness to purchase. Asia Pacific Management Review 15(3): 359-376.

Huang YA et al. 2008. Allocentrism and consumer ethnocentrism: social identity on purchase intention. Social Behavior and Personality 36(8): 1097-1110.

Khan A, Khan A, Ahmad H, Shafique MN. 2018. Consumer' willingness to buy foreign products: effect of consumer animosity and ethnocentrism. Sarhad Journal of Management Sciences 4(2): 144-160.

Khan H, Daryanto A, Liu C. 2019. How anticipated regret influences the effect of economic animosity on consumers' reactions towards a foreign product. International Business Review 28(2): 405-414. https://doi.org/10.1016/j.ibusrev.2018.12.008

Kiriri PN. 2019. Consumer perception: animosity, ethnocentrism and willingness to buy chinese products. European Journal of Marketing and Economics 2(1): 32-46.

Klein J G, Ettenson R, Morris MD. 1998. The animosity model of foreign product purchase: an empirical test in the people's republic of China. Journal of Marketing 62(1): 89-100.

Leong SM. et al. 2008. Understanding an international and consequences consumer crisis: animosity nature, antecedents, and consequences. Journal of International Business Studies 39(6): 996-1009. https://doi.org/10.1057/palgrave.jibs.8400392.

Nguyen TD, Nguyen TTM, Barrett NJ. 2008. Consumer ethnocentrism, cultural sensitivity, and intention to purchase local products - evidence from Vietnam. Journal of Consumer Behaviour 7:88100. https://doi.org/10.1002/cb.

Quang NN, DinhChien T, Long NH. 2017. The effects of consumer ethnocentrism and consumer animosity on the willingness to buy with the mediating role of products judgments: children's food case. Advances in Economics and Business 5(8): 466-475. https://doi.org/10.13189/ aeb.2017.050805.

Rahmawati NA, Muflikhati I. 2016. Effect of consumer ethnocentrism and perceived quality of product on buying behavior of domestic and foreign food products: a case study in Pekanbaru, Riau, Indonesia. Journal of Consumer Science 1(1):113.

Ramadania, Gunawan S, Jamaliah. 2013. Country of origin effect and animosity on the attitude and purchase intention of foreign products. Asean Marketing Journal 5(1): 59-68. 
Remar D, Campbell J, Dipietro RB. 2016. The impact of local food marketing on purchase decision and willingness to pay in a foodservice setting. Journal of Foodservice Business Research 19(1): 89-108. https://doi.org/10.1080/15378020.2016 .1129224.

Riptiono S. 2019. Does Islamic religiosity influence female muslim fashion trend purchase intention? an extended of theory of planned behavior. Iqtishadia: Jurnal Kajian Ekonomi Dan Bisnis Islam 12(1): 16-36.

Saffu K, Walker JH, Mazurek M. 2010. The role of consumer ethnocentrism in a buy national campaign in a transitioning country. International Journal of Emerging Markets 5(2): 203-226. https://doi.org/10.1108/17468801011031829.

Selli M, Kurniawan H. 2014. Effects of animosity and allocentrism toward consumer ethnocentrism in shaping consumers' willingness to purchase: a case study on consumers in Greater Jakarta (Jabodetabek Area) in Purchasing Malaysian Products. Asean Marketing Journal 6(1): 1-14.

Shankarmahesh MN. 2006. Consumer ethnocentrism: an integrative review of its antecedents and consequences. International Marketing Review 23(2): 146-172. https://doi. org/10.1108/02651330610660065.

Sharma S, Shimp TA, Shin J. 1995. Consumer ethnocentrism: a test of antecedents and moderators. Academy of Marketing Science 23(1): 26-37.

Shin YH, Hancer M. 2016. The role of attitude, subjective norm, perceived behavioral control, and moral norm in the intention to purchase local food products. Journal of Foodservice Business Research 19(4): 338-351. https://doi.org/10.108 $0 / 15378020.2016 .1181506$

Siamagka N, Balabanis G. 2015. Revisiting consumer ethnocentrism: review, reconceptualization, and empirical testing. Journal of International Marketing 23(3): 66-86.

Souiden N, Ladhari R, Chang L. 2018. Chinese perception and willingness to buy taiwanese brands the role of ethnocentrism and animosity. Asia Pacific Journal of Marketing and Logistics 30(4): 816-836.https://doi.org/10.1108/APJML09-2017-0203.

Triandis HC. 1989. The self and social behavior in differing cultural contexts. Psychological Review 96(3): 506-520.

Verlegh PWJ. 2007. Home country bias in product evaluation: the complementary roles of economic and socio-psychological motives. Journal of International Business Studies 38: 361-373. https://doi.org/10.1057/palgrave.jibs.8400269.

Wang CL, Chen ZX. 2004. Consumer ethnocentrism and willingness to buy domestic products in a developing country setting: testing moderating effects. Journal of Consumer Marketing 21(6): 391-400. https://doi. org/10.1108/07363760410558663.

Yen YS. 2018. Extending consumer ethnocentrism theory: the moderating effect test. Asia Pacific Journal of Marketing and Logistics 30(4): 907926. https://doi.org/10.1108/APJML-09-20170226. 